\title{
İKİNCİ ÜRÜN PAMUKTA (Gossypium hirsutum L.) YAPRAK DÖKTÜRÜCÜ KİMYASALLARIN ÖNEMLİ MORFOLOJIKK ÖZELLIKKLER ÜZERİNE ETKİSİ
}

\author{
Ahmet Serdar TÜLEMEN', Mustafa Ali KAYNAK ${ }^{2}$ \\ Özet \\ Bu çalıșmanın amacı; ikinci ürün koșullarında, farklı sıcaklılarda çalıșabilen yaprak döktürücü dozları ve yaprak \\ döktürücü uygulama yöntemlerinin pamuğun önemli morfolojik özellikleri üzerine etkisini belirlemektir. \\ Araştırmada materyal olarak, Gossypium hirsutum L. türüne ait Flash çeşidi kullanılmıştır. Deneme, 2014 \\ yıllında Adnan Menderes Üniversitesi Ziraat Fakültesi Araştırma ve Uygulama Çiftliğinde, bölünmüş parseller \\ deneme desenine göre, üç tekerrürlü olarak, sıra arası $70 \mathrm{~cm}$, sıra uzunluğu $12 \mathrm{~m}$ olan, 8 sıralı parsellerde \\ yürütülmüştür. \\ Yaprak döktürücü uygulama yöntemlerinin yaprak sayısı (21. gün hariç) üzerine istatistikî yönden önemli olduğu \\ belirlenirken, yaprak döktürücü dozlarının ise yaprak sayısı, yaprak döküm oranı üzerine istatistikî yönden \\ önemli olduğu belirlenmiştir. Çalışmada yaprak döktürücü uygulamalarının keskin bıçak yöntemine göre \\ uygulanmasının daha yararlı olacağı sonucuna varılmıştır. \\ Denemede yaprak döktürücü uygulama zamanını belirlemek için kullanılan yöntemlerin ve dozların toplam koza \\ sayısı, açık koza sayısı ve açık koza oranı üzerine istatistikî yönden önemli olmadığı saptanmıştır. \\ Anahtar Kelimeler: Pamuk, defoliant, morfolojik özellikler
}

\section{The Effects of Defoliants on Important Morphological Features on Short Season Cotton (Gossypium hirsutuml.)}

\begin{abstract}
The aim of this study was to determine the effects of defoliants doses which can operate at different temperatures and methods of administration of the important morphological cotton defoliant on agriculture. Gossypium hirsutum L. Flash kinds of species were used for this study. The research was carried out in 2014 at Adnan Menderes University, Faculty of Agriculture, Research and Application Farm, in accordance with the split plot experimental design, as three replication, with row spacing of $70 \mathrm{~cm}$ and the length of $12 \mathrm{~m}$ in the 8-row plots.

Effect of the defoliant application methods were determined to important on the leaf number (except to 21. day) level as statistical. Also doses of defoliant were found important as statistical for leaf number, leaf defoliation rate. As a result of this study were obtained application of defoliant more useful with sharp knife.

The study was conducted for determining to the time of defoliant application effect of the applications and defoliant doses on the total boll number, open boll number, rate of the open boll were determined to unimportant as statistical.
\end{abstract}

Keywords: Cotton, defoliant, morphological properties

\section{GíRiş}

Pamuk 1950'li yıllardan itibaren çeşitli ülkelerde makineyle hasat edilmeye başlanmıştır. Pamuk toplamada en önemli ölçüt, hasada zamanında başlayıp en kısa zaman içerisinde hasadın tamamlanmasıdır. Pamuk ne kadar kısa zamanda toplanırsa, karşılaşılacak riskler de o oranda azalacaktır. Tarım sektöründe yeterli işgücü bulunamaması ve beklenmeyen hava faaliyetleri pamuk toplama işini sıkıntıya sokan iki önemli unsurdur. Pamuğun hasadı geciktikçe yağmur riski artmakta, yağmurdan sonra hasat edilen pamuğun kalitesi düşmektedir. Hatta ürün, toplama işçisi kıtlığından ve zamansız yağışlardan dolayı tarlada kalabilmektedir. Makineli hasat, hasadın daha ucuz ve daha kısa sürede yapılmasını sağlamaktadır (Mert, 2007).

Makine ile pamuk hasadında kütlülerin çepelsiz toplanabilmesi ve makineden optimum performans alınabilmesi için defoliant kullanımı zorunludur (Sokat, 2008).

Ülkemizde pamuk hasadında makine kullanımı ve hasada yardımcı kimyasal uygulamaları önemli ölçüde artmıştır. Hasada yardımcı kimyasallar uygulama zamanı, uygulama başarısı, makine performansı ile birlikte doğrudan verim ve lif kalitesi üzerine etki yapmaktadır. Bu kimyasalların uygulamasında yapılacak hatalar verimi ve özellikle kaliteyi azaltmaktadır. Yapılan çalışmalarda, hasada yardımcı uygulamalara rağmen makine ile toplanan pamuklardaki yabancı madde miktarının el ile toplanan pamuklardan daha yüksek olduğu saptanmıştır (Özbek, 2011).

Kimyasalların kullanımı yaygınlaşmasına rağmen ikinci ürün tarımda, ana üründe olduğu gibi aynı dozlarda kimyasal kullanımı istenen sonuçları vermemekte bunun sebebi olarak ise iklim koşulları karşımıza çıkmaktadır. Özellikle ikinci ürün tarım alanlarında hasat Ekim veya Kasım ayına denk 
gelmesi sebebiyle hava sıcaklıklarındaki düşmeler defoliantların çalışmasını olumsuz etkilemektedir. Ülkemizde kullanılan defoliantlar genellikle hava sicaklıklarının $15^{\circ} \mathrm{C}$ ve üzeri olduğu dönemlerde iyi sonuçlar vermekte fakat bunun altındaki sıcaklıklarda çalışmaları yavaşlamakta ya da durmaktadır. Bu hem bitkinin metabolik aktivitesindeki yavaşlamaya ve buna bağlı olarak defoliantın bitkiye girișini engellemektedir. Sonuç olarak istenen düzeyde defoliasyon (yaprak döktürme) sağlanamamaktadır. Bunun önüne geçmek için ya serin koşullarda çalışabilen defoliantlar kullanılmalı ya da uygun doz oranlarının yeniden belirlenmesi gerekmektedir. Bunun yanında, defoliant uygulama zamanı belirli bazı yöntemlere göre yapılmaktadır. Defoliasyon işleminin başarılı olması uygun zamanda kullanıma bağlıdır.

$\mathrm{Bu}$ çalıșma, ikinci ürün koșullarında, farklı sıcaklılarda çalıșabilen defoliant dozları ve defoliant uygulama yöntemlerinin pamuğun önemli morfolojik ve tarımsal özellikleri üzerine etkisini belirlemek amacıyla yapılmıştır.

\section{MATERYALve YÖNTEM}

Çalışmada, bölgenin standart çeşitlerinden olan ve aynı zamanda ikinci ürün koșullarında da ekilebilen Flash pamuk çeșidi materyal olarak kullanılmıștır.

Çalışma, Adnan Menderes Üniversitesi Ziraat Fakültesi Araştırma ve Uygulama Çiftliğinde, 2014 yılı pamuk yetiştirme döneminde yürütülmüştür. Deneme, Bölünmüș Parseller Deneme Desenine göre ana parsel yaprak döktürücü (defoliant) uygulama yöntemi (koza açım yöntemi ve keskin bıçak yöntemi), alt parsel doz olacak şekilde iki faktörlü olarak 3 tekerrürlü ve her bir alt parsel 12 metre uzunluğunda ve 8 siralı olarak kurulmuștur. Ekim işlemi 09 Haziran 2014 tarihinde gerçekleştirilmiş olup, diğer kültürel işlemler normal üretim koşullarına göre yapılmıştır.

Denemenin kurulduğu alanda toprak yapısının homojen olmaması nedeniyle 1.tekerrürde yer alan bitkiler daha erken su isteği belirtisi göstermiştir.

Yaprak döktürücü uygulama zamanını belirlemede Koza Açım Yöntemi ve Keskin Bıçak Yöntemi olmak üzere iki farklı yöntem uygulanmıştır.

Denemede hasada yardımcı kimyasalların etkilerini görmek adına düşük sıcaklıkta çalıșabilen yaprak döktürücü (defoliant) olarak thidiazuron+diuron etkili maddeli kimyasal ve dört farkl1 dozu $60 \mathrm{cc} / \mathrm{da}, 70 \mathrm{cc} / \mathrm{da}, 80 \mathrm{cc} / \mathrm{da}$ ve $90 \mathrm{cc} / \mathrm{da}$ olmak üzere 02.11.2014 tarihinde uygulanmıștır. Ayrıca her parsele koza açtırıcı olarak mepiquat+chloride kimyasalından $100 \mathrm{ml} / \mathrm{da}$ uygulanmıștır. Hasat elle bir defa da 20 Aralık 2014 tarihinde alt parsellerin orta 4 sirası hasat edilerek yapılmıştır. Hasatta her parselin baş ve sonunda birer metre, yanlarından ise ikişer sıra kenar tesiri olarak bırakılmıştır.

Çalışmada, defoliant uygulama öncesinde ve uygulama sonrasinda 7., 14. ve 21. günlerde koza ve yaprak sayımları yapılmış olup, toplam koza sayısı, açık koza sayısı, koza açım oranı, yaprak sayısı ve yaprak döküm oranı özellikleri incelenmiştir.

\section{BULGULAR ve TARTIŞMA}

Çalışmada, yaprak döktürücü (defoliant) uygulama öncesi toplam koza sayısı, açık koza sayısı ve koza açım oranı değerleri Çizelge 1'de gösterilmiştir.

Çizelge 1'de, yaprak döktürücü uygulama öncesinde toplam koza sayısının koza açım yönteminin uygulanacağı parsellerde ortalama 11.67 adet, keskin bıçak yönteminin uygulanacağ 1 parsellerde ortalama 11.39 adet olduğu, doz uygulamalarının yapılacağı parsellerde ise ortalama 13.07 adet $(60 \mathrm{cc} / \mathrm{da})$ ile 10.20 adet (kontrol) arasinda olduğu görülmektedir.

Çizelge 1'de yaprak döktürücü uygulama öncesinde açık koza sayısı değerlerinin (adet/bitki) koza açım yönteminin uygulanacağ ortalama 3.32 adet, keskin bıçak yönteminin uygulanacağ 1 parsellerde ise ortalama 3.57 adet olduğu, doz uygulamalarının yapıldığ ortalama 1.53 adet (kontrol) ile 4.88 adet $(60 \mathrm{cc} / \mathrm{da})$ oranında olduğu görülmektedir.

Çizelge 1'de, yaprak döktürücü uygulama öncesi koza açım oranı değerlerinin koza açım yönteminin uygulanacağ 1 parsellerde ortalama \%26.84, keskin bıçak yönteminin uygulanacağı parsellerde ortalama \% 31.69 olduğu, doz uygulaması yapılacağ1 parsellerde ise oranın \%15.03 (Kontrol) ile \%45.73 $(80 \mathrm{cc} / \mathrm{da})$ oranında değiştiği görülmektedir.

Yaprak döktürücü uygulama öncesi koza açım oranlarının \%60'ın altında kalmasının nedeni hedef koza yerine bitkideki tüm kozalar dikkate alınarak yapılmasından kaynaklanmaktadır.

Yaprak döktürücü uygulamasının 7., 14. ve 21. gününde toplam koza sayısı, açık koza sayısı ve koza açım oranına ilișkin varyans analizi kareler ortalaması değerleri Çizelge 2'de verilmiștir.

Çizelge 2'de, uygulamanın 7., 14. ve 21. gününde toplam koza sayısı, açık koza sayısı ve koza açım oranı yönünden yöntem, doz ve yöntem $\mathrm{x}$ doz interaksiyonları arasında istatistikî yönden önemli farklılıkların oluşmadı̆̆ 1 belirlenmiștir.

Yaprak döktürücü uygulamasının 7., 14. ve 21. gününde toplam koza sayısı, açık koza sayısı ve koza açım oranı değerleri Çizelge 3, 4 ve 5'de verilmiştir.

Koza sayımları ile ilgili toplam koza sayısı, açık koza sayısı ve koza açım oranları birlikte incelendiğinde, yaprak döktürücü uygulamalarından sonraki 7., 14. ve 21. günlerde üç özelliğe de yaprak döktürücü uygulama yöntemlerinin ve dozlarının önemli etkisinin olmadığı görülmüştür. Uygulama öncesindeki açık koza sayısı ve koza açım oranları 
yaprak döktürücü uygulamasıyla birlikte artmış ancak bu artış kontroldeki artıştan farklı olmamıștır. Kullanılan yaprak döktürücünün koza açtırıcı özelliği olmasına karşın kontrole göre farklılığın oluşmamasında, uygulama sonrası oluşan yağış ve sıcaklık değerlerinin etkili olabileceği düşünülmektedir.

Denemede elde edilen toplam koza sayıları incelendiğinde Sokat (2008)'ın 6.6 ile 7.9 adet/bitki arasında bulmuş olduğu değerler bizim değerlerimizden düşüktür.

Çopur et al. (2010) 2001 ve 2002 yılında yapmış olduğu çalışmadan sırasıyla 15.80-17.77 adet/bitki, 15.53-20.92 adet/bitki değerler elde ettiği belirtilmiş ve bu değerler bizim elde ettiğimiz değerlerden yüksektir.

Kaynak et al. (1999) 1997 ve 1998 yıllarında yürütmüş olduğu çalışmada, Nazilli 84 ve Deltapine 5690 çeşitlerini materyal olarak kullandıklarını bildirmiştir. Çalışmadan elde edilen koza verileri incelendiğinde 10.37 ile 20.33 adet/bitki arasında olduğu belirtilmiş ve bizim çalışmamızda elde edilen değerden yüksektir.

2012 yılında yapılan çalışmada, denememizde kullanılan yaprak döktürücünün muadili olan Cut Out ticari isimli kimyasal ve bunun yanında Süper Boll ticari isimli koza açtırıcı kullanıldığı bildirilmiştir. Bahsi gecen kimyasalların uygulanmasından sonraki 7. günde $\% 93$ ve 14 . günde $\% 100$ koza açımı sağladığ 1 bildirilmiş ve 7 . ve 14 . günler arasında $\% 7$ oranında koza açımı olduğu görülmekte ve artış oranı bizim bulgularımızla uyum sağlamaktadır (Anonim, 2013).

Kullanılan yaprak döktürücünün çalışma sıcaklığ incelendiğinde; Barber et al. (2013) ve Özbek (2011) belirttiklerine göre denemede kullandığımız kimyasalın muadili olan Ginstar (thidazuron+diuron) ticari isimli yaprak döktürücünün minimum çalışma sıcaklıkları 15.6oC olarak belirtilmiştir. Ancak, yaprak döktürücü uygulamasının yapıldığ 2 Kasım 2014 Pazar günü sicaklık değerleri max. 21.1oC, min.12.4oC ve ortalama değer $13.80 \mathrm{C}$ olarak kaydedildiği görülmektedir (Anonim, 2015). Wills ve Snipes (1996)'e göre gece sicaklıkları 15.6oC'nin altına düştüğünde ise Dropp adlı yaprak döktürücünün önerilmemesi gerektiği belirtilmiştir.

Yaprak döktürücü uygulama sonrası 7., 14. ve 21. günde yaprak sayısı ve yaprak döküm oranına ilişkin varyans analizi kareler ortalaması Çizelge 6'da verilmiştir.

Çizelge 6'da, dozlar arasında uygulama sonrası 7., 14. ve 21. günde yaprak sayısı ve yaprak döküm oranı yönünden önemli düzeyde farklılığın olduğu, yöntemler arasında sadece uygulama sonrası 7. ve 14.günde yaprak sayısı yönünden önemli düzeyde farklılığın olduğu, yöntem $\mathrm{x}$ doz interaksiyonunun ise önemli olmadığı görülmektedir.

Yaprak döktürücü uygulama öncesi yaprak sayıs1 ile uygulama sonrası 7. günde yaprak sayıs1, yaprak döküm oranları ve oluşan gruplar Çizelge 7'de verilmiştir.

Çizelge 7'de, yaprak döktürücü uygulama öncesi yaprak sayısının koza açım yönteminin uygulanacağı parselde ortalama 47.97 adet, keskin bıçak yönteminin uygulanacağı parselde 41.52 adet olduğu, doz uygulamalarının yapılacağı parsellerde ortalama 38.03 adet ( $60 \mathrm{cc} / \mathrm{da})$ ile 50.07 adet ( $80 \mathrm{cc} / \mathrm{da})$ arasında değiştiği görülmektedir.

Çizelge 7'de, uygulamanın 7. gününde keskin bıçak yönteminin koza açım yöntemine göre yaprak sayısını önemli oranda azalttığ 1 , yaprak sayısının keskin bıçak yönteminde 26.44 adet, koza açım yönteminde ise 29.36 adet olduğu görülmektedir. Aynı çizelgede doz uygulamalarının kontrole göre yaprak sayısını önemli oranda azalttığ 1 , en az yaprağın 20.43 adet ile $90 \mathrm{cc} /$ da uygulamasında, en fazla yaprağın ise 45.00 ile kontrolde olduğu görülmektedir.

Çizelge 7'de, uygulamanın 7. gününde doz uygulamalarının kontrole göre yaprak dökümünü önemli oranda arttırdığı en fazla yaprak dökümünün $\% 49.58$ ile $90 \mathrm{cc} / \mathrm{da}$ doz uygulamasinda, en az dökümün ise \% 10.07 ile kontrol parselinde olduğu, doz uygulamaları arasında da önemli farklılık olduğu görülmektedir.

Yaprak döktürücü uygulama sonrası 14. ve 21. günde yaprak sayısı ve yaprak döküm oranı değerleri ve oluşan gruplar Çizelge 8 'de verilmiştir.

Çizelge 8'de, uygulamanın 14.gününde kekin bıçak yönteminin, koza açım yöntemine göre yaprak sayısını önemli oranda azalttığ 1 , yaprak sayısının keskin bıçak yönteminde 13.23 adet, koza açım yönteminde ise 16.57 adet olduğu görülmektedir. Aynı çizelgeden, doz uygulamalarının kontrole göre yaprak sayısını önemli oranda azalttığı, en az yaprağın 8.20 adet ile $60 \mathrm{cc} / \mathrm{da}$ doz uygulamasında, en fazla yaprağın ise 34.93 adet ile kontrolde olduğu ve doz uygulamaları arasında önemli oranda fark olduğu görülmektedir.

Çizelge 8'de, uygulama sonrası 14. günde doz uygulamalarının kontrole göre yaprak dökümünü önemli oranda arttırdığg1, en fazla yaprak dökümünün $\% 78.77$ ile $60 \mathrm{cc} /$ da doz uygulamasinda, en az yaprak dökümünün ise \%30.17 ile kontrolde olduğu, doz uygulamaları arasında ise önemli bir farklılık olmadığı görülmektedir.

Çizelge 8'de, 21. günde doz uygulamalarının kontrole göre yaprak sayısını önemli oranda azalttığ1, en az yaprağın 1.57 adet ile $90 \mathrm{cc} / \mathrm{da}$ doz uygulamasında, en fazla yaprağın ise 28.13 adet ile kontrolde olduğu ve doz uygulamaları arasında önemli bir farklılık olmadığı görülmektedir.

Çizelge 8'de, 21. günde doz uygulamalarının kontrole göre yaprak dökümünü önemli oranda arttırdığ 1 , en fazla dökümün \%96.12 ile $80 \mathrm{cc} / \mathrm{da}$ doz uygulamasında, en az dökümün ise \%43.73 ile kontrolde olduğu ve doz uygulamaları arasında önemli bir farklılık olmadığı görülmektedir.

Yaprak sayımları ile ilgili yaprak sayısı ve 
yaprak döküm oranları birlikte incelendiğinde, yaprak döktürücü uygulamalarından sonraki 7., 14. ve 21. günlerde yaprak döktürücü doz uygulamalarının yaprak döküm oranını kontrole göre önemli oranda arttırırken, yaprak sayısını da kontrole göre önemli oranda azalttığ 1 görülmüştür. Yaprak döktürücü uygulama yöntemlerinin ise her üç dönemde de yaprak dökümü oranına önemli etkilerinin olmadığı, 7. ve 14. günlerdeki yaprak sayımlarına ise önemli etkilerinin olduğu ve keskin bıçak yönteminin koza açım yöntemine göre bu dönemlerde yaprak sayımını önemli oranda azalttığı belirlenmiştir. Yaprak döktürücü uygulamasının 21. gününde uygulama yapılan parsellerde yaklaşık \% 94-97 yaprak dökümü gerçekleşirken, kontrol parselinde ise yaklaşık \% 44 oranında yaprak dökümü gerçekleșmiștir. $\mathrm{Bu}$ da beklenildiği gibi yaprak döktürücü uygulamasının yaprak dökümüne etkili olduğunu göstermektedir.

Cathey (1985)'in yapmış olduğu, soğuk ve geç sezon uygulamalarından elde edilen veriler bizim çalışmamızdaki verilerle örtüşmektedir.

Snipes ve Cathey (1992)'in yapmış olduğu çalışmada (1987 yılında elde edilen) yaprak döküm oranlarına ilişkin 7. gündeki $\% 26-79$ ve (1986 ve 1987 y1lında elde edilen) 14.gündeki \%55-83, \%1983 elde ettiği verilerle çalıșmamızdaki veriler uyum göstermiştir.

Nelson ve Hart (1994) yılında yapmış olduğu çalışmada bulmuş olduğu değerler bizim çalışmamızda elde edilen değeri destekler niteliktedir.

Nelson (1995), Ginstar defoliantı uyguladığ 1 alanlardan elde ettiği değerler incelendiğinde uygulama sonrasi 7.,14. ve 18. günlerdeki yaprak döküm oranları incelendiğinde, sırasıyla \%40, \%70 ve \% 86 olduğu görülmekte ve bizim çalışmamızı destekler niteliktedir.

Gwathmey ve Hayes (1997), geç ekim yapılan pamukta yaprak döktürücü uygulamasından 7 ve 14 gün sonra yaparak sayımlarının, 1994 yılında sırasıyla $\% 33-85$ ve $\% 63-91$ arasında, 1995 y1linda $\% 20-81$ ve \%29-86 arasinda, 1996 yilinda ise \%10-86 ve \%11-94 arasında olduğu belirtilen çalışmayla bizim çalışmamız kısmen uyum göstermiştir.

Sokat (2008), yaprak sayısı üzerine elde ettiği değerler 60.2-45.2 arasında olup bulgularımız bu çalışma ile kısmen uyum göstermiştir.

(Anonim, 2013)'ün çalışmasında, yaprak döktürücü uygulamasından sonraki 7 . günde $\% 70.8$ 80,14 . günde $\% 96.8-97.8$ ve 24 . gün ise $\% 96.5-99.3$ yaprak dökümü görüldüğü bildirilmiş olup 7. ve 14 . günlerde elde edilen veriler bizim bulgularımızla uyum sağlamazken,24. günde elde edilen veriler bizim 21. günde elde etiğimiz verilerle kısmen uyum sağlamaktadır.

Genel anlamda denemeden elde ettiğimiz sonuçlara göre yaprak döktürücü uygulama yöntemi olarak keskin bıçak yönteminin daha uygun olduğu ve dozlar arasında ise belirgin bir fark olmadığ görülmüştür. Uygulanacak olan yaprak döktürücünün çalışma sıcaklığının ve etki mekanizmasının iyi bilinmesi gerektiği sonucuna varılmıştır. Ekim yapılan alandaki toprak yapısı farklılıklarının kimyasal üzerine dolaylı yoldan etkisi olduğu düşünülmektedir. Bundan dolayı tarladaki pamukların üniform şekilde yetiştirilmesi ve yaprak döktürücülerinin etiket bilgileri doğrultusunda uygulama yapılması gerekmektedir.

Sonuç olarak ikinci ürün pamuk tarımında uygun yetiştirme koşulları ve uygun çeşit seçimiyle birlikte düşük sıcaklık koşullarında çalışabilen yaprak döktürücü kullanılmasının daha yararlı olacağı sonucuna varılmıștır.

Çizelge 1. Uygulama Öncesi Toplam Koza Sayısı (adet/bitki), Açık Koza Sayısı (adet/bitki) ve Koza Açım Oranı (\%) Değerleri

\begin{tabular}{|c|c|c|c|c|c|c|c|c|c|}
\hline \multirow{2}{*}{ Doz } & \multicolumn{3}{|c|}{ Toplam Koza Sayıs1 (adet/bitki) } & \multicolumn{2}{c|}{ Açı Koza Sayıs1 (adet/bitki) } & \multicolumn{3}{c|}{ Koza Açım Oranı (\%) } \\
\cline { 2 - 10 } & KAY & KBY & Ortalama & KAY & KBY & Ortalama & KAY & KBY & Ortalama \\
\hline $60 \mathrm{cc} / \mathrm{da}$ & 14.73 & 11.40 & 13.07 & 4.40 & 5.20 & 4.88 & 27.15 & 49.97 & 38.56 \\
\hline $70 \mathrm{cc} / \mathrm{da}$ & 12.73 & 11.67 & 12.20 & 3.87 & 3.07 & 3.47 & 30.57 & 25.87 & 28.22 \\
\hline $80 \mathrm{cc} / \mathrm{da}$ & 10.67 & 11.33 & 11.00 & 5.30 & 5.10 & 5.20 & 45.85 & 45.60 & 45.73 \\
\hline $90 \mathrm{cc} / \mathrm{da}$ & 10.00 & 12.33 & 11.17 & 2.53 & 3.47 & 3.00 & 22.07 & 26.63 & 24.35 \\
\hline Kontrol & 10.20 & 10.20 & 10.20 & 1.53 & 1.53 & 1.53 & 15.03 & 15.03 & 15.03 \\
\hline Ortalama & 11.67 & 11.39 & & 3.32 & 3.57 & & 26.85 & 31.69 & \\
\hline
\end{tabular}

KAY: Koza Açım Yöntemi, KBY: Keskin Bıçak Yöntemi 
Çizelge 2.Uygulama Sonrası Toplam Koza Sayısı, Açık Koza Sayısı ve Koza Açım Oranına İlişkin Varyans Analizi Kareler Ortalamas1

\begin{tabular}{|c|c|c|c|c|c|c|c|c|c|}
\hline \multirow[b]{2}{*}{$\begin{array}{c}\text { Varyasyon } \\
\text { Kaynağ1 }\end{array}$} & \multicolumn{3}{|c|}{ 7.Gün } & \multicolumn{3}{|c|}{ 14.Gün } & \multicolumn{3}{|c|}{ 21.Gün } \\
\hline & $\begin{array}{c}\text { Toplam } \\
\text { Koza } \\
\text { Say1s1 }\end{array}$ & $\begin{array}{c}\text { Açık } \\
\text { Koza } \\
\text { Sayıs1 }\end{array}$ & $\begin{array}{l}\text { Koza } \\
\text { Açım } \\
\text { Oranı }\end{array}$ & $\begin{array}{c}\text { Toplam } \\
\text { Koza } \\
\text { Say1s1 }\end{array}$ & $\begin{array}{c}\text { Aç1k } \\
\text { Koza } \\
\text { Sayıs1 }\end{array}$ & $\begin{array}{l}\text { Koza } \\
\text { Açım } \\
\text { Oranı }\end{array}$ & $\begin{array}{c}\text { Toplam } \\
\text { Koza } \\
\text { Sayıs1 }\end{array}$ & $\begin{array}{l}\text { Açık } \\
\text { Koza } \\
\text { Sayı1sı }\end{array}$ & $\begin{array}{l}\text { Koza } \\
\text { Açım } \\
\text { Oranı }\end{array}$ \\
\hline Tekerrür & 5.308 & 27.416 & 334.904 & 4.769 & 37.801 & $2880.63 *$ & 4.929 & $18.105^{*}$ & 1753.049 \\
\hline Yöntem & 0.481 & 0.055 & 614.089 & 0.192 & 0.008 & 29.613 & 2.821 & 2.465 & 7.5 \\
\hline Hata-1 & 4.769 & 5.114 & 534.878 & 3.724 & 4.064 & 127.816 & 0.329 & 0.729 & 102.352 \\
\hline Doz & 10.219 & 5.27 & 1.617 & 13.112 & 3.099 & 120.58 & 3.875 & 1.578 & 110.623 \\
\hline $\begin{array}{c}\text { Yöntem x } \\
\text { Doz }\end{array}$ & 6.668 & 4.126 & 281.351 & 5.685 & 4.776 & 388.717 & 3.205 & 1.362 & 165.59 \\
\hline Hata-2 & 8.48 & 2.129 & 263.838 & 8.512 & 2.306 & 138.535 & 5.316 & 2.744 & 60.678 \\
\hline Genel & 7.72 & 4.908 & 354.335 & 7.881 & 5.464 & 371.229 & 4.369 & 3.303 & 199.793 \\
\hline
\end{tabular}

*:\%5 seviyesinde önemli, **:\% 1seviyesinde önemli

Çizelge 3. Uygulama Sonrası 7.günde Toplam Koza Sayısı (adet/bitki), Açık Koza Sayısı (adet/bitki) ve Koza Açım Oranı (\%) Değerleri

\begin{tabular}{|c|c|c|c|c|c|c|c|c|c|}
\hline \multirow{2}{*}{ Doz } & \multicolumn{3}{|c|}{ Toplam Koza Sayıs (adet/bitki) } & \multicolumn{3}{c|}{ Aç1k Koza Sayıs (adet/bitki) } & \multicolumn{3}{c|}{ Koza Açım Oranı (\%) } \\
\cline { 2 - 10 } & KAY & KBY & Ortalama & KAY & KBY & Ortalama & KAY & KBY & Ortalama \\
\hline $60 \mathrm{cc} / \mathrm{da}$ & 14.73 & 11.40 & 13.07 & 5.30 & 6.20 & 5.84 & 22.27 & 58.13 & 40.20 \\
\hline $70 \mathrm{cc} / \mathrm{da}$ & 12.60 & 11.67 & 12.13 & 5.27 & 4.00 & 4.63 & 40.50 & 33.23 & 36.87 \\
\hline $80 \mathrm{cc} / \mathrm{da}$ & 10.67 & 11.27 & 10.97 & 5.70 & 3.07 & 4.12 & 30.90 & 25.97 & 28.43 \\
\hline $90 \mathrm{cc} / \mathrm{da}$ & 9.93 & 12.33 & 11.13 & 3.20 & 5.00 & 4.10 & 30.67 & 40.33 & 35.50 \\
\hline Kontrol & 9.60 & 9.60 & 9.60 & 3.13 & 3.13 & 3.13 & 32.90 & 32.90 & 32.90 \\
\hline Ortalama & 11.51 & 11.25 & & 4.37 & 4.28 & & 31.45 & 38.11 & \\
\hline
\end{tabular}

KAY: Koza Açım Yöntemi, KBY: Keskin Bıçak Yöntemi

Çizelge 4. Uygulama Sonrası 14.Günde Toplam Koza Sayısı (adet/bitki), Açık Koza Sayısı (adet/bitki) ve Koza Açım Oranı (\%) Değerleri

\begin{tabular}{|c|c|c|c|c|c|c|c|c|c|}
\hline \multirow{2}{*}{ Doz } & \multicolumn{2}{|c|}{ Toplam Koza Say1s1 (adet/bitki) } & \multicolumn{2}{c|}{ Açık Koza Sayıs1 (adet/bitki) } & \multicolumn{3}{c|}{ Koza Açım Oranı (\%) } \\
\cline { 2 - 10 } & KAY & KBY & Ortalama & KAY & KBY & Ortalama & KAY & KBY & Ortalama \\
\hline $60 \mathrm{cc} / \mathrm{da}$ & 14.33 & 11.40 & 12.87 & 5.10 & 6.33 & 5.84 & 33.85 & 60.03 & 49.56 \\
\hline $70 \mathrm{cc} / \mathrm{da}$ & 12.47 & 11.67 & 12.07 & 5.60 & 4.60 & 5.10 & 44.17 & 39.23 & 41.70 \\
\hline $80 \mathrm{cc} / \mathrm{da}$ & 10.67 & 11.20 & 10.93 & 6.50 & 3.53 & 4.72 & 52.90 & 30.90 & 39.64 \\
\hline $90 \mathrm{cc} / \mathrm{da}$ & 9.93 & 12.33 & 11.13 & 3.40 & 5.27 & 4.33 & 32.20 & 41.83 & 37.02 \\
\hline Kontrol & 8.93 & 8.93 & 8.93 & 3.87 & 3.87 & 3.87 & 43.83 & 43.83 & 43.83 \\
\hline Ortalama & 11.27 & 11.11 & & 4.75 & 4.72 & & 41.09 & 43.15 & \\
\hline
\end{tabular}

KAY: Koza Açım Yöntemi, KBY: Keskin Bıçak Yöntemi 
İkinci Ürün Pamukta (Gossypium hirsutum L.) Yaprak Döktürücü Kimyasalların Önemli Morfolojik Özellikler Üzerine Etkisi

Çizelge 5. Uygulama Sonrası 21.Günde Toplam Koza Sayısı (adet/bitki), Açık Koza Sayısı (adet/bitki) ve Koza Açım Oranı (\%) Değerleri

\begin{tabular}{|c|c|c|c|c|c|c|c|c|c|}
\hline \multirow{2}{*}{ Doz } & \multicolumn{2}{|c|}{ Toplam Koza Sayıs1 (adet/bitki) } & \multicolumn{2}{|c|}{ Açık Koza Sayısı (adet/bitki) } & \multicolumn{3}{c|}{ Koza Açım Oranı (\%) } \\
\cline { 2 - 11 } & KAY & KBY & Ortalama & KAY & KBY & Ortalama & KAY & KBY & Ortalama \\
\hline $60 \mathrm{cc} / \mathrm{da}$ & 11.47 & 10.47 & 10.97 & 5.80 & 7.53 & 6.47 & 51.17 & 70.13 & 60.65 \\
\hline $70 \mathrm{cc} / \mathrm{da}$ & 10.33 & 10.60 & 10.47 & 7.67 & 7.20 & 7.43 & 75.47 & 67.97 & 71.72 \\
\hline $80 \mathrm{cc} / \mathrm{da}$ & 9.27 & 10.13 & 9.70 & 6.27 & 7.13 & 6.37 & 64.97 & 63.93 & 64.45 \\
\hline $90 \mathrm{cc} / \mathrm{da}$ & 8.80 & 11.73 & 10.27 & 5.73 & 6.47 & 6.63 & 67.57 & 62.13 & 64.85 \\
\hline Kontrol & 8.87 & 8.87 & 8.87 & 6.07 & 6.07 & 6.07 & 68.97 & 68.97 & 68.97 \\
\hline Ortalama & 9.75 & 10.36 & & 6.32 & 6.88 & & 65.63 & 66.63 & \\
\hline
\end{tabular}

KAY: Koza Açım Yöntemi, KBY: Keskin Bıçak Yöntemi

Çizelge 6. Uygulama Sonrası Yaprak Sayısı ve Yaprak Döküm Oranına İlişkin Varyans Analizi Kareler Ortalaması

\begin{tabular}{|c|c|c|c|c|c|c|}
\hline \multirow{2}{*}{$\begin{array}{c}\text { Varyasyon } \\
\text { Kaynağ1 }\end{array}$} & \multicolumn{2}{|c|}{7. Gün } & \multicolumn{2}{c|}{14. Gün } & \multicolumn{2}{c|}{21. Gün } \\
\cline { 2 - 7 } & $\begin{array}{c}\text { Yaprak } \\
\text { Sayı1 }\end{array}$ & $\begin{array}{c}\text { Yaprak Döküm } \\
\text { Oran1 }\end{array}$ & Yaprak Sayıs1 & $\begin{array}{c}\text { Yaprak Döküm } \\
\text { Oranı }\end{array}$ & $\begin{array}{c}\text { Yaprak } \\
\text { Sayı1 }\end{array}$ & $\begin{array}{c}\text { Yaprak Döküm } \\
\text { Oranı }\end{array}$ \\
\hline Tekerrür & $67.548^{*}$ & 394.549 & $18.252^{* *}$ & 95.563 & 11.641 & 2.574 \\
\hline Yöntem & $63.948^{*}$ & 20.336 & $84.001^{* *}$ & 117.612 & 6.721 & 0.065 \\
\hline Hata-1 & 0.868 & 37.04 & 0.177 & 34.819 & 19.361 & 4.722 \\
\hline Doz & $593.623^{* *}$ & $1565.032^{* *}$ & $761.027^{* *}$ & $2592.154^{* *}$ & $792.988^{* *}$ & $3235.206^{* *}$ \\
\hline $\begin{array}{c}\text { Yöntem x } \\
\text { Doz }\end{array}$ & 49.771 & 63.229 & 16.241 & 137.451 & 13.608 & 5.053 \\
\hline Hata-2 & 16.926 & 28.374 & 5.918 & 56.245 & 15.948 & 5.68 \\
\hline Genel & 105.006 & 270.709 & 114.642 & 420.576 & 122.423 & 450.577 \\
\hline
\end{tabular}

*:\%5 seviyesinde önemli, **:\% 1seviyesinde önemli 
Çizelge 7. Uygulama Öncesi ve Uygulama Sonrası 7.Günde Yaprak Sayısı (adet/bitki), Yaprak Döküm Oranı (\%) Değerleri ve Olușan Gruplar

\begin{tabular}{|c|c|c|c|c|c|c|c|c|c|}
\hline \multirow{2}{*}{ Doz } & \multicolumn{3}{|c|}{$\begin{array}{l}\text { Uygulama Öncesi Yaprak } \\
\text { Sayısı (adet/bitki) }\end{array}$} & \multicolumn{3}{|c|}{$\begin{array}{l}\text { Uygulama Sonras1 7.Günde } \\
\text { Yaprak Sayıs1 (adet/bitki) }\end{array}$} & \multicolumn{3}{|c|}{$\begin{array}{l}\text { Uygulama Sonras1 7.Günde } \\
\text { Yaprak Döküm Oranı (\%) }\end{array}$} \\
\hline & KAY & KBY & Ortalama & KAY & KBY & Ortalama & KAY & KBY & Ortalama \\
\hline $60 \mathrm{cc} / \mathrm{da}$ & 57.87 & 29.60 & 38.03 & 28.07 & 16.13 & $22.10 \mathrm{c}++$ & 51.47 & 41.80 & $46.63 \mathrm{a}^{++}$ \\
\hline $70 \mathrm{cc} / \mathrm{da}$ & 46.80 & 43.73 & 39.73 & 27.20 & 28.40 & $27.80 \mathrm{~b}$ & 42.07 & 35.83 & $38.95 \mathrm{~b}$ \\
\hline $80 \mathrm{cc} / \mathrm{da}$ & 46.60 & 42.80 & 50.07 & 26.87 & 21.47 & $24.17 \mathrm{bc}$ & 41.80 & 48.83 & $45.32 \mathrm{ab}$ \\
\hline $90 \mathrm{cc} / \mathrm{da}$ & 38.67 & 41.47 & 46.40 & 19.67 & 21.20 & $20.43 \mathrm{c}$ & 49.27 & 49.90 & $49.58 \mathrm{a}$ \\
\hline Kontrol & 50.00 & 49.07 & 49.53 & 45.00 & 45.00 & $45.00 \mathrm{a}$ & 10.07 & 10.07 & $10.07 \mathrm{c}$ \\
\hline Ortalama & 47.97 & 41.52 & & $29.36 \mathrm{~A}+$ & $26.44 \mathrm{~B}$ & & 38.93 & 37.29 & \\
\hline $\operatorname{LSD}(\% 5)$ & & & - & & & 5.038 & & & 6.52 \\
\hline
\end{tabular}

+Büyük harfler, yöntemlere göre dozların önem düzeyleri ve oluşturmuş olduğu gruplarl ifade etmektedir.

++ Küçük harfler, dozlara göre yöntemlerin önem düzeyleri ve oluşturmuş olduğu gruplart ifade etmektedir.

KAY: Koza Açım Yöntemi, KBY: Keskin Bıçak Yöntemi

Çizelge 8. Uygulama Sonrası 14. ve 21. Günde Yaprak Sayıs1 (adet/bitki), Yaprak Döküm Oran1 (\%) Değerleri ve Oluşan Gruplar

\begin{tabular}{|c|c|c|c|c|c|c|c|c|c|c|c|c|}
\hline \multirow{2}{*}{ Doz } & \multicolumn{3}{|c|}{$\begin{array}{l}\text { Uygulama Sonrası 14.Günde } \\
\text { Yaprak Sayıs1 (adet/bitki) }\end{array}$} & \multicolumn{3}{|c|}{$\begin{array}{l}\text { Uygulama Sonras1 14.Günde } \\
\text { Yaprak Döküm Oranı (\%) }\end{array}$} & \multicolumn{3}{|c|}{$\begin{array}{l}\text { Uygulama Sonras1 21.Günde } \\
\text { Yaprak Sayıs1 (adet/bitki) }\end{array}$} & \multicolumn{3}{|c|}{$\begin{array}{l}\text { Uygulama Sonras1 21.Günde } \\
\text { Yaprak Döküm Oranı (\%) }\end{array}$} \\
\hline & KAY & KBY & $\underset{\mathrm{a}}{\text { Ortalam }}$ & KAY & KBY & Ortalama & KAY & KBY & Ortalama & KAY & KBY & Ortalama \\
\hline $60 \mathrm{cc} / \mathrm{da}$ & 10.27 & 6.13 & $8.20 \mathrm{c}++$ & 82.40 & 75.13 & $78.77 \mathrm{a}++$ & 1.93 & 8.20 & $5.07 \mathrm{~b}++$ & 96.60 & 94.00 & $95.30 \mathrm{a}++$ \\
\hline $70 \mathrm{cc} / \mathrm{da}$ & 12.07 & 11.00 & $11.53 \mathrm{~b}$ & 74.40 & 74.77 & $74.58 \mathrm{a}$ & 2.20 & 2.07 & $2.13 \mathrm{~b}$ & 95.33 & 95.20 & $95.27 \mathrm{a}$ \\
\hline $80 \mathrm{cc} / \mathrm{da}$ & 14.40 & 5.93 & $10.17 b c$ & 68.33 & 85.90 & $77.12 \mathrm{a}$ & 2.33 & 1.13 & $1.73 \mathrm{~b}$ & 94.86 & 97.37 & $96.12 \mathrm{a}$ \\
\hline $90 \mathrm{cc} / \mathrm{da}$ & 11.20 & 8.13 & $9.67 \mathrm{bc}$ & 71.00 & 80.13 & $75.57 \mathrm{a}$ & 1.67 & 1.47 & $1.57 \mathrm{~b}$ & 95.57 & 96.27 & $95.92 \mathrm{a}$ \\
\hline Kontrol & 34.93 & 34.93 & $34.93 \mathrm{a}$ & 30.17 & 30.17 & $30.17 \mathrm{~b}$ & 28.13 & 28.13 & $28.13 \mathrm{a}$ & 43.73 & 43.73 & $43.73 \mathrm{~b}$ \\
\hline Ortalama & $16.57 \mathrm{~A}+$ & $13.23 \mathrm{~B}$ & & 65.26 & 69.22 & & 7.25 & 8.20 & & 85.22 & 83.21 & \\
\hline $\begin{array}{l}\text { LSD } \\
(\% 5)\end{array}$ & \multicolumn{2}{|c|}{0.66} & 2.98 & & 9.18 & & 4.89 & & 2.92 \\
\hline
\end{tabular}

+Büyük harfler, yöntemlere göre dozların önem düzeyleri ve oluşturmuş olduğu gruplarl ifade etmektedir.

++ Küçük harfler, dozlara göre yöntemlerin önem düzeyleri ve oluşturmuş olduğu gruplarl ifade etmektedir.

KAY: Koza Açım Yöntemi, KBY: Keskin Bıçak Yöntemi 


\section{KAYNAKLAR}

Anonim (2013) Cotton Defoliation, The University of Georgia. http://blog.extension.uga.edu/ applingcrop/2013/10/cotton-defoliation/, (Erişim Tarihi:08.10.2015).

Anonim (2015) Adnan Menderes Üniversitesi Ziraat Fakültesi Meteoroloji İstasyonu Verileri, Aydın.

Barber LT, Hayes RM, Dodds DM, Reynolds DB (2013) Mid-South Cotton Defoliation Guide, University of Arkansas Division of Agriculture, Lonoke, Arkansas 111. http://cdm16039.contentdm.oclc.org/cdm/ $\mathrm{ref} /$ collection/p266101 coll7/id/26326 (Erișim Tarihi:26.05.2015).

Cathey GW (1985) Conditioning Cotton For Increased Response to Defoliant Chemicals, Field Crops Research 10: 347-353.

Çopur O, Demirel U, Polat R, Gür MA (2010) Effect of different defoliants and application times on the yield and quality components of cotton in semi-arid conditions. African Journal of Biotechnology 9(14): 2095-2100.

Gwathmey CO, Hayes RM (1997) Harvest-Aid Interactions under Different Temperature Regimes in Field-Grown Cotton http://www.cotton.org/journal/199701/1/upload/jcs01-001.pdf (Erişim Tarihi: 10.10.2015)

Kaynak MA, Unay A, Başal H, Serter E (1999) Pamukta yaprak döktürücü uygulama zamanın önemli tarımsal ve lif kalite özelliklerine etkisinin saptanması. In: Türkiye 3. Tarla bitkileri kongresi Bildirileri, Cilt II, Endüstri Bitkileri, 15-18 Kasım 1999, Adana, 150-154.

Mert M (2007) Pamuk Tarımının Temelleri . TMMOB Ziraat Mühendisleri Odası Teknik Yayınlar Dizisi No:7, Ankara.

Nelson JM, Hart GL (1994) Defoliation Research on Upland and Pima Cotton at the Maricopa Agricultural Center in 1994. http://arizona.openrepository.com/ arizona/bitstream/10150/210254/1/370099-040045.pdf (Erișim Tarihi: 08.10.2015).

Nelson JM (1995) Effects of Combinations of Accelerate and Other Defoliants on Defoliation of Upland Cotton, http://arizona.openrepository.com/arizona/bitstream/1 0150/210753/1/370103-053-056.pdf (Erişim Tarihi: 08.10.2015).

Özbek N (2011) Ege Tarımsal Araștırma Enstitüsü Müdürlügüü \& İzmir Gıda Tarım ve Hayvancılık İl Müdürlüğü 2011 Y1lı Tarla Bitkileri Grubu Bölge Bilgi Alışveriş Toplantısı Bildirileri, 22-24 Kasım 2011, İzmir, 48 .

Snipes CE, Cathey GW (1992) Evoliation of defoliant mixture in cotton. Field Crop Research, 28(4): 327334.

Sokat Y (2008) İkinci Ürün Pamuk Tarımında Defoliant Uygulamalarının Verim, Lif Ve Tohum Kalitesi Üzerine Etkilerinin Araştırılması. Doktora Tezi, Ege Üniversitesi, İzmir.

Wills GD, Snipes CE (1996) Influence of Various on Activity of Dropp ${ }^{\circledR}$ Defoliant on Cotton. Mississippi $\mathrm{S} t \mathrm{at}$ e University, Starkville. http://msucares.com/pubs/bulletins/b1049.htm (Erișim Tarihi: 10.10.2015)

\section{Sorumlu Yazar}

MustafaAli KAYNAK

mkaynak@adu.edu.tr

Adnan Menderes Üniversitesi, Ziraat Fakültesi,

Tarla Bitkileri Bölümü, AYDIN

Geliş Tarihi $\quad: 10.02 .2016$

Kabul Tarihi $\quad: 15.02 .2016$ 